\title{
Mitterrand and the Great European Design-From the Cold War to the European Union ${ }^{1}$
}

\author{
David Ramiro Troitiño \\ Tallinn University of Technology, \\ Akadeemia tee 3, \\ Tallinn 12618, Estonia \\ E-mail: david.troitino@ttu.ee
}

Karoline Färber

University of Erfurt

Nordhäuser Straße 63

Erfurt 99089, Germany

E-mail: karoline.faerber@uni-erfurt.de

Anni Boiro

London School of Economics and Political Science

London WC2A 2AE, United Kingdom

E-mail:A.P.Boiro@lse.ac.uk

Abstract: François Mitterrand had a leading role in directing the course for the European integration process. While he orchestrated the economic integration of Europe, he remained deeply opposed to further political integration within the Communities. This article researches Mitterrand's rationale for his clear focus on economic affairs and develops his vision for the institutional setting of the European Union (EU). The focus of the article is allocated to four different perspectives that reflect the four pillars of Mitterrand's European policy: the common currency, the establishment of a closely integrated and small Western European based EU, the development of the Social Europe and of a free trade area between Europe and Africa. It is argued that although EU institutions have been established based on Mitterrand's design, today's reality deviates from the conditions on which his plan was based. For Mitterrand, the ideal EU involved a deep-rooted Western Europe with France at its core and a loose

1 This work was supported by the Jean Monnet module Functional Capacity of the European Union, under grant VERT672, European Community Framework Programme Erasmus + Jean Monnet. 
association with Central and Eastern Europe. His perception resembles the current discussions of multi-speed Europe and the determination of France and Germany to proceed to the next stage of the integration process. Importantly, Mitterrand's print can still be recognised in the EU's social policy included in the treaties, yet still far from being implemented. Notably, like all of the French Presidents, Mitterrand developed a design for Africa in which an extensive free trade area between Europe and former French colonies were to be established. In this proposal, Germany was to be assigned the part of the economic engine behind the actualisation of the proposal, while France was to carry out the role of a required middle man of the transactions. To further assure France's political predominance over the Communities, Mitterrand designed a common currency for a small number of homogenous Western-European states.

Keywords: European crisis, European integration, eurozone, François Mitterrand, future of the $E U$

\section{Introduction}

François Mitterrand has attracted fascination across the globe as one of the key European leaders of the second half of the 20th century. The end of the Cold War and the collapse of the Communist regimes in Central and Eastern Europe situated him at the epicentre of a critical moment in European history. This enabled him to influence greatly the design for the European Union's (EU) institutions. Mitterrand's print can still be recognised today, most notably with regard to the EU's common currency, the euro.

With regard to the European integration process, Mitterrand has been actively involved in European politics since his earlier political career as a French delegate at the Congress of Europe in The Hague in 1948. Consisting of over 800 assistants, including Churchill, Adenauer, Spinelli and van Zeeland, the event witnessed a number of different proposals for the building process of Europe. Opposing the British and Nordic delegates' cooperation proposals, the French delegates supported the idea of a federal Europe. However, the beginning of Mitterrand's political career included involvements in nationalist movements like the Union Démocratique et Social de la Résistance (UDSR), which were followed by a transition towards leftist ideology. Mitterrand also advocated for the rapid ratification of the European Coal and Steel Community Treaty 
in the French National Assembly (see Débats, 1951), while expressing his concern in regard to the impact that the Communities might have on the French Empire, particularly on the African territories. This demonstrates Mitterrand's understanding of the French foreign policy as a single unit including several factors; Europe and Africa being just different components of the same equation (Cayrol, 1967).

The presidential campaign of 1965 between de Gaulle and Mitterrand reflected two contrasting perceptions of the French society together with two considerably differentiating models of Europe-a state-centred community as opposed to a federal proposal. Mitterrand voiced a clear federal statement when he expressed his trust on a political supranational authority which would manage the European affairs. This proclamation directed extensive support for Mitterrand's benefit, including the so-called father of Europe, Jean Monnet (Magoud, 1986). During the 1970s, Mitterrand became the leader of the French Socialist Party, which held anti-integration as an essential faction of the party. As the unity of the party took Mitterrand's priority, his interventions regarding the European Communities were consciously mitigated. Instead, Mitterrand's focus was directed towards internal coherence. He commonly emphasised the importance of the development of a Social Europe, a popular socialist idea, obviating controversial issues mostly linked with the transfer of sovereignty from the national to the European level.

During his Presidency of France from 1981 to 1995, Mitterrand was remarkably active in the European affairs. His policy towards Europe could be characterised as following four main premises:

- Priority of France's autonomy and independence vis-à-vis the USA and the USSR, while protecting the national interest through the introduction of the euro;

- Federalist approach combined with critical decisions under the Council's control;

- Internal consensus about Europe;

- Key strategic relationship with Germany (see Tiersky, 1995).

When Jacques Delors became the President of the Commission in 1985, the influence of France in the communitarian affairs was elevated resulting in the Single European Act (SEA) of 1986 being approved a month earlier than the French legislative elections were to take place. This treaty's importance in the European development is undeniable as it created a real European market by abolishing national trade obstacles. Followed by the fall of the Berlin Wall soon after, the Monetary Union underwent an acceleration, thus increasing 
the international cooperation of the Member States as they adopted a common position towards the German reunification. With the help of the introduced events, the EU was created in 1992. This outstanding period of alterations from a fragile community to a tangible union was highly influenced by Mitterrand in its key aspects, which leads to a discussion of the four pillars on which Mitterrand's design was based.

The research question addressed in this article is if the euro's design and the current problems of the eurozone are the results of a misconception of Mitterrand's blueprint for Europe. As the paper explores the intentions and achievements of the French President with regards to the EU, it reveals the misconstruction of the common currency to identify the origin of this error.

The methodology of the research is based on historiography, or scientific history. It has been applied in three different stages:

1. Heuristic - a search for sources consisting of all the available information on the relation of Mitterrand and the European integration process, resulting in collection of documents, reports, newspaper articles and secondary sources;

2. Critique - the validity or invalidity of contradictory versions was evaluated;

3. Synthesis - the data and information were embedded so that they fit into the general framework of the research, connecting the verified information with the causes and with the consequences thereof.

The research revealed four different areas where Mitterrand worked to have an impact on the EU's structure: the proposal for a European Confederation, the relation between Europe and Africa, the development of a Social Europe, and the German reunification. These four general areas are developed in the research in a way of understanding the creation of the common currency, the euro. 


\section{The Great European Design}

\subsection{The European Confederation}

The collapse of the Communist bloc and the disintegration of the USSR entailed critical changes on the European continent and, consequently, in the European Communities, resulting in the accession of new members. The Birkelbach Doctrine (1962) established that prospective member states must fulfil the three basic conditions: to be a democratic state; to have a functioning economy based on free market; and to be located in Europe (Powell, 2015).

The former communist countries of Central and Eastern Europe soon converted to capitalism and reformed their political systems from unitarism to democracy, fulfilling, at least in theory, the membership requirements of the European Communities. Their intentions of becoming full members of the organisation clashed with Mitterrand's design for Europe, which composed of an increase in integration amongst the Western European states and an association of the Central and Eastern European countries (Kerikmäe et al., 2016) in a new organisation with looser ties in the political field but with participation in the European market.

The European Confederation sponsored by Mitterrand had three main targets:

- Accommodate the USSR in Europe and protect Gorbachev in the internal process of reforms to avoid new confrontation;

- Collaborate with the former members of the communist area in Central and Eastern Europe without integrating them into the rest of Europe to keep these countries under the influence of the Union and hence under France's leadership;

- $\quad$ Pave the path for deeper integration in Western Europe by eliminating the Soviet and Central European obstacles by creating three differentiated areas or circles: (1) an integrated federalist Western Europe, (2) a Common Market including Central and Eastern Europe, and (3) cooperation with the USSR in security issues.

The European Confederation envisioned by François Mitterrand was extended from the Atlantic to the Urals. Thus, it included the USSR, a country whose protection was necessary in ensuring stability in Europe according to Mitterrand, Thatcher and even the West German Foreign Affairs Minister Hans-Dietrich Genscher (Salmon, 2010). The significance in the cooperation, hence, lay in the fact that the USSR was neither a companion nor a member in the integration process (see Delors, 2004). 
The involvement of the USSR in the pan-European community was also necessary for the creation of a deeper union amongst Western European statesan embryo of a future world power (Bozo, 2009). As a result, the hard nucleus would have remained under the political domination of France as the more integrated states would have acted in concert in the new European organisation.

Furthermore, Mitterrand aspired to turn France into an alternative to the USA in the field of international relations for he aimed to replace the USSR as a fundamental element of duality in global supremacy with a wide economic area formed by Western European states and politically dominated by France (Braghiroli, 2009). Despite this intention, Mitterrand quickly gained support from the Soviet President Mikhail Gorbachev, the USSR's chief interlocutor for a pan-European construction (Sakwa, 1990). ${ }^{2}$

Mitterrand's design did not succeed due to his ambiguity regarding the various fragments involved in the establishment process of the European Confederation. Although this was deliberate as a part of his political strategy, it quickly turned against him with the proposal of a 'step-by-step approach' that lacked a defined final goal (Newton, 2013). Subsequently, Mitterrand focused on concrete measures for the near future. These clashed against the necessities and wishes of the other parts involved in the progression of the implementation of his plans, as the new democracies of Europe desired full integration with Western Europe and full membership in the EU, and the USSR sought for participation in a European Community based on intergovernmentalism rather than federalism.

\subsection{Europe and Africa}

Mitterrand's influence over the communitarian relations with Africa derived directly from his understanding of the European Communities and later the EU as an organisation politically dominated by France that brought direct benefits to the latter (Ramiro Troitiño, 2008). The idea of creating a common European action towards Africa was de facto an acceptance of French leadership; in other words, it was the transfer of the traditional French involvement in Africa to

2 Initially, the USSR aimed at a wider European security and political framework that included the area from Lisbon to Vladivostok. When this proved to be impossible, Gorbachev supported a European Confederation to fortify a wider security association of 32 states to avoid the rise of a new world power in Europe as a Confederation would have prevented the implementation of common economic, foreign and defence policy capacities (see Védrine, 2016). However, Gorbachev failed to take into consideration Mitterrand's pragmatism as well as his determination to achieve political control over a new world power, filling the vacant position left by the USSR (see Newton, 2003). 
a European framework greatly influenced by France. Even though Africa had traditionally been a vast area of French international influence, it was threatened by the worldwide extension of the Cold War. The confrontation between the USA and the USSR had an immense impact in the reorganisation of the postcolonial world as it became a battlefield for the international expansion of two different societal models. However, the incapacity of Western European powers to compete in the bipolar world was clearly demonstrated in the course of the Suez Crisis (Dooley, 1989), when the Anglo-French action against the nationalisation of this crucial transport hub was not supported by the USA and turned out as a great disaster for the national interests of France and the UK.

In the footprints of de Gaulle, Mitterrand pursued an independent European foreign policy in order to protect the national interests of France. The unbearably high cost of acting independently was balanced with the involvement of the European Communities in the African affairs; a combined action from a community of states which lacked political integration, again, enabled the domination of French leadership. Essentially, the major agenda behind the strategy was to further maximise the international influence and greatness of France, with the resources of the rest of the Communities' members. Evidently, Mitterrand wanted to play a leading role in the external relations of the Union (Rieker, 2006).

Mitterrand started his presidential term with a third-world socialist orientation calling for an end to the postcolonial French policy in Africa, especially regarding the dictators supported by former French Presidents Charles de Gaulle and Giscard d'Estaing. At the Cancun Conference on Third World Development in 1981 he gave a speech regarding Africa, stressing the necessity of greater investments from Europe in order to help developing the African economies. By actualising Mitterrand's proposal, Europe would have assumed its responsibility for the creation of new markets and customers to the European economies. Concerning migration, Mitterrand proposed economic development translating to citizens' stability in terms of international mobility. The EU Commission reacted to Mitterrand's ideas with a proposal for a new EEC-African Economic and Security Pact, with the intention of increasing the economic aid enormously while exploring the possibility of the creation of a free trade area between Africa and the European Communities (Haastrup, 2013).

Clearly, Mitterrand's idea for Africa-France relations under the communitarian umbrella needed the sustenance provided by Germany, but he did not encounter the support expected due to concerns over the financial cost and the divergence between French and German international interest for Germany prioritised 
relations with Central and Eastern Europe. Consequently, Mitterrand attempted to reduce France's financial burden by a multilateralisation of the costs with francophone Africa. During the French-African summit of 1994, he launched an idea of an inter-African peacekeeping force-a combined military force of African countries to be deployed in African countries previously colonised by France in the case of necessity, with the logistical support of France. Mitterrand was paving the way towards multilateralism, burden-sharing and cost limitation, yet again, under the French political leadership (Dawson, 2014).

The lack of European support towards Mitterrand's plan, combined with the reluctance of the African countries to participate in the inter-African peacekeeping force, reflected the incapacity of France to take the lead in a multilateral approach. Subsequently, Mitterrand reformed his original design by acting unilaterally in Africa solely on the basis of the French national interests. ${ }^{3}$ His first minister for cooperation, Jean-Pierre Cot, resigned as a protest in this exceptional political change. Perhaps this turned into Mitterrand's favour, as he got to appoint his own son, Jean-Christophe, as the Élysée's African policy advisor; an unprecedented decision which shaped the personal control of Mitterrand over the African policy of France and Europe. Jean-Christophe's involvement in private businesses with a number of African dictators strongly recalled the actions of Mitterrand's predecessors, thus resembling the previous and typical French pattern in the African affairs.

\subsection{Social Europe}

Before Mitterrand's involvement, the European Communities had based their development on a shared management of a common European market with the aim of eliminating physical barriers to intra-communitarian trade and establishing common external borders. The integration, fundamentally economic, did neither include common social policies nor mitigated the pernicious effects of the market economy on the weakest elements of the system. The basic social redistribution of the wealth generated by the capitalist economy was managed individually by the Member States while the market itself was common, thus providing greater benefits to those economic agents that operated in the European level, which were commonly medium- and large-sized companies. This situation served the USSR with a chance to criticise the European integration process as a capitalist tool under the influence of the USA against the workers of Europe, clearly having an impact on Mitterrand's policies.

3 For instance, the unilateral French intervention in the Rwandan genocide in 1994 resembled a traditional pattern of French intervention in African affairs. 
Mitterrand proposed the building of a Community for the people's and workers' benefit. His ideas were based on a society that functions with a market economy, but with a high level of social protection communitarising a part of the benefits in order to achieve a balanced social reality based on equal opportunities and the protection of the least favoured by the market (Ramiro Troitiño, 2013). This was not a new concept in Mitterrand's vision for European integration. In fact, he had included them in his arguments already in the late 1960s and since then had aimed at the Europeanisation of the social features. Mitterrand even stated that Europe will be nothing until a defined European social policy had been realised (Lauber, 1983). This implied a confrontation of two integration models: the Europe of merchants versus the Europe of people - a debate that is still alive in the contemporary world.

Consequently, after being elected president in 1981, Mitterrand made the Europeanisation of the social policy a basic complement to the European market for its proper functioning. In the process, however, he realised the opposition of important European partners such as the UK, the Netherlands, and Germany. The UK rejected the idea of a social policy in the Communities as their national model was distant from the continental social framework which had been implemented in the rest of the Communities' members. ${ }^{4}$ The AngloSaxon model advocated for a reduced state intervention in the market beyond its basic regulation and lower public unemployment protection in order to foster participation in the labour market, reducing the expenditures of the state and increasing its revenues. While the continental social system is more costly and less competitive, it is more effective in terms of equality. Germany and the Netherlands were more concerned about the competitiveness of their economies, as social policies are intertwined with employment and unemployment policies, taxes, basic state services and other measures that clearly have a big impact on economic agents. The negative response of the European partners together with difficult domestic social reforms (see Cole, 1999) eliminated the chances of successful inclusion of social aspects in the European integration at the beginning of Mitterrand's term.

The creation of a real European market without national obstacles to the intra-communitarian trade and measures of equivalent effect were introduced by the SEA in 1986. Although Mitterrand displayed during the negotiations the opportunity to include social aspects in the development of the European market, the rest of the members' resilient opposition (especially the UK) led the proposal to a dead end (Moravcsik, 1991). However, the rapid evolution of

$4 \quad$ Italy's Mediterranean model was the only exception to the continental framework. 
Europe due to the end of the Cold War paved the way for more cooperation in the social aspects, and during the 1989 Council (under the French Presidency), the Social Charter and Social Action Programme came to the fore. By the time of the Maastricht Summit in 1991, only the UK opposed a social chapter in the EU text (Haywood, 1993). Subsequently, when the Social Policy of the EU came into force in 1992 in the Treaty of Maastricht, the UK negotiated an optout that removed the main obstacle for the implementation of a common policy in this field.

The creation of a Social Europe signified (and still does) the convergence of the different social models of Europe; a key element in the national identity of each European nation and hence, a highly problematic area to be integrated (Lewis, 1998). Subsequent treaties have increased the European role in social features, yet a defined European social policy remains inexistent in the present daywithout any concrete indicators of it being implemented at any time in the near future. Even though Mitterrand created the framework for further development of a Social Europe, its sustenance has remained weak due to a lack of political will in Europe to push for deeper integration in this ground. Hence, the EU currently lacks the social features that could provide coherence to the European integration project.

\subsection{German reunification, economic integration and the common currency}

Mitterrand's stance on economic integration is based on the special FrancoGerman relationship and on the necessity to firmly integrate a reunified Germany into the Communities. While West Germany assumed economic leadership of the Communities after WWII, France was eager to secure its political predominance over communitarian affairs. To this aim, Mitterrand chose economic means, namely the creation of an economic monetary union (EMU) including a common currency. At first, this plan was met with scepticism, especially by the UK (Ramiro Troitiño et al., 2015). Disagreements culminated in the British crisis, which was finally solved under the auspices of Mitterrand in 1984. Subsequently, preconditions for a single market were set up within two years.

It was in this context that the idea of a multi-speed Europe was first accomplished: as a single market logically can only fully function when common costs are reduced, Mitterrand and Kohl agreed to gradually abolish controls at the FrancoGerman border in 1984. This triggered a spill-over effect from the bilateral to the European area (Germond, 2012, p. 200): only one year later, the Schengen agreement was signed by all members of the Communities. Although this 
agreement enormously favoured the power position of both West Germany and France, it was Mitterrand who clearly took on the leading role due to the division of Germany, which provided for an asymmetrical distribution of power between the partners.

The Communities' common objective was stated for the first time in the SEA (1986), namely the creation of an economic and monetary union, including a single market, by 1992. Article 13 of the SEA defines the single market as an "area without internal frontiers in which the free movement of goods, persons, services and capital is ensured" (Single European Act, 1987). According to the timeline set forth in the SEA, an intergovernmental conference on a monetary union was to be held to discuss possible designs of such union. West Germany, however, refused to agree to a date due to large domestic protests demanding the unification of West and East Germany. European politicians' and leaders' reactions to the possibility of unification ranged from scepticism to blunt refusal, fearing the threat that might originate from a newly strengthened Germany. Mitterrand, too, rejected the possibility of a unified Germany. When domestic protests did not stop and the USSR signalled its approval to German reunification, Mitterrand had to accept that a unification proved to be an unstoppable development. When Kohl finally agreed to hold a conference before the end of 1990, he demanded a statement of approval by the Communities, in which they were to recognise the unification process. Mitterrand agreed as he recognised a prime opportunity to firmly integrate a newly unified Germany in the Communities through economic means.

The Treaty of the European Union of 1992, today known as the Maastricht Treaty, was the outcome of this process. It set forth the aim to establish a common currency by 1999 and enshrined the objective of an EMU in its Protocol on the Statute of the European System of Central Banks. While this step would "effectively eliminate the monetary sovereignty of the Community's members" (Lange, 1993, p. 5), as it expanded the competencies of the newly founded European Central Bank (ECB), a common currency would further unify the member states of the Communities. Satisfying the French security interests, Mitterrand thus "anchor[ed] a now greatly enlarged and strengthened Germany into a more vigorous, more permanent, organic form of European Community" (Berend, 2016, p. 172) that found its major expression in the creation of the euro.

In the following development process of the EMU, Mitterrand proposed a union that would focus solely on economic issues arising from the introduction of a common currency. Doing so, he had a two-fold aim: On the one hand, he wanted 
to improve France's bargaining position vis-à-vis Japan and the USA, which were the economic superpowers at that time, by strengthening the Communities. On the other hand, Mitterrand anticipated to consolidate French predominance over European affairs. To him, a political union had several strategic flaws, including a bettering of Germany's position ${ }^{5}$ and a reduction of the value of France's special prerogatives in the area of security and defence policy. ${ }^{6}$ Consequently, he stressed the economic benefits of the introduction of a common currency: the euro "will be the strongest [currency] in the world, stronger than the dollar, because it will be much more stable and will allow Europe to assert itself as the first economic power on the planet" (quoted in Short, 2013, p. 519).

It is important to note that Mitterrand did not envisage any further enlargement of the Communities when drafting his plan for the EMU. As shown above, he aspired a deeply integrated Western Europe under French leadership with amicable relations with Central and Eastern Europe. A common currency then served as the focal point in his European design, firmly integrating states that had a similar economic performance. Today, however, the eurozone counts 19 highly heterogeneous members (see, for example, Schwab, 2016). As a result, the occurrence of asymmetrical crises becomes more likely.

An asymmetrical crisis is a shock of the economic system that affects various parts of the system differently: while France and Germany recovered quickly after the Eurozone crisis of 2010, a severe blow has been dealt to Greece's economy. This shows an inherent flaw in the EU's common currency: as it was designed for a homogenous, small group of states, the ECB lacks the instruments to effectively counter an asymmetrical crisis. Due to the widely different economic performances of eurozone members, financial tools such as devaluation or revaluation of a currency can never reflect the reality of all economies. While Greece, for example, is in dire need for a devaluation of the euro, this would overheat the German economy. Thus, a common currency precludes vigorous action in times of crisis and leaves weaker economies in the system largely unprotected. The question remains whether or not the euro would function better if Mitterrand's plan had been fully adapted, including a deeply integrated homogeneous Western core.

$5 \quad$ As Sperling (1993, p. 209) notes: "Germany has acquiesced to political union to allay fears of a hegemonial Germany without however sacrificing its leadership role", especially with regards to Central and Eastern Europe. As such, a political union would have favoured Germany over France.

6 A political union would have made a common security and defence policy necessary, therefore "reducing the value of $[\ldots]$ the special prerogatives and status which France [...] possess[ed]" (Pedersen, 1998, p. 154). France's status resulted directly from being a victor of WWII and its possession of nuclear weapons. 


\section{Conclusion}

Mitterrand has been a fundamental architect of the EU due to of his considerable work in the European integration process. However, his central status as the political leader of the European Communities evaporated subsequently as the sole political power of France dissolved into the duple of Chirac-Schroeder and Sarkozy-Merkel. Gradually, Germany has achieved the position of Europe's economic leadership, although shaded by its belligerent past when it comes to political leadership.

Mitterrand's design rested on the four pillars of the establishment of a European Confederation, the creation of a free trade area with Africa, the introduction of a Social Policy at the European level and the advancement of economic integration through a common currency. As has been shown, his plan was not fully implemented at the European level, thus creating a dysfunction in the organisation. The premises assumed by Mitterrand were not accepted by other important partners in the integration process and his plan was not executed according to the original idea. Hence, the reality does not equal the design, creating a malfunction that needs to be solved. The current EU is facing several problems, including the financial crisis and its consequences, the lack of political leadership, Brexit, the lack of social policies in a common market or effective relations with African partners.

As this article has analysed, it is clear that the construction of any item without following the original design leads to a failure to function in a normal or satisfactory manner. Hence, the EU needs to reform to readapt to the real situation. Currently, there are different options under discussion, including multi-speed Europe where Western European states can collaborate inspecific policy areas, the development of the European Defence Project, or the creation of European taxes which would translate to Member States having their own incomes (see, for example, European Commission, 2017). In this context, a historiographic analysis of Mitterrand's European design clarifies the past and helps us to understand the current problems.

The euro is part of a plan that was not fully implemented, making it impossible for its preconditions to be met. The euro was designed for a smallnumber of states with a higher level of economic integration. Following through with Mitterrand's plans would have made an asymmetrical crisis, the weakest point of the European currency during the last economic crisis in 2010 less likely. Hence, new tools must be developed in order to avoid asymmetrical crisis as they are not included in the original design. 
David Ramiro Troitiño, PhD is a senior lecturer at Tallinn Law School of Tallinn University of Technology. Dr. Troitino obtained his doctoral degree from Salamanca University. He has more than 70 publications such as articles in peer-reviewed academic journals, chapters in books, doctoral dissertation, and conference papers. His research fields of interest are the European Union, EU integration, EU Neighbourhood policy and contemporary political studies.

Karoline Färber is an undergraduate student of International Relations and Social Sciences at the University of Erfurt, Germany. She works as a student researcher at the Chair for International Relations. Her research interests include foreign and security policy, in particular with regard to transatlantic relations, German-Russian relations and the European Union.

Anni Boiro is a postgraduate student of Development Management at the London School of Economics and Political Science (United Kingdom). She has conducted studies in Australia and Africa with her sphere of research interest focusing on several aspects related to Europe and Sub-Saharan Africa, International Relations, North-South and Humanitarian politics.

\section{References}

Berend, I. T. (2016), The History of European Integration: A new perspective, London/ New York: Routledge.

Bozo, F. (2009), Mitterrand, the End of the Cold War, and German Unification, New York \& London: Berghahn Books.

Braghiroli, S. \& Carta, C. (2009), “An index of friendliness toward Russia: An analysis of the member states and Member of the European Parliament's positions," PanEuropean Institute Electronic Publication. Retrieved from https:/www.utu.fi/ fi/yksikot/tse/yksikot/PEI/raportit-ja-tietopaketit/Documents/Braghiroli_\%20 Carta\%201509\%20web.pdf [accessed 11 Sep 2017]

Cayrol, R. (1967), François Mitterrand: 1945-1967, Paris: Presses de Sciences Po.

Cole, A. (1999), 'French socialists in office: Lessons from Mitterrand and Jospin,' Modern \& Contemporary France, vol. 7, no. 1, pp. 71-87. https://doi.org/10.1080/09639489908456471

Dawson, S. (2014), “Revitalising France's military relevance in Central Africa: Central Africa - issue in focus," Africa Conflict Monthly Monitor, vol. 2014, no. 9, pp. 56-60.

Débats (1951), Débats parlamentaires de la 4ème République et constituantes, Assemblée Nationale, Journal officiel de la République Française, 18.11.1951. 
Delors, J. (2004), Mémoires, Paris: PLON.

Dooley, H. J. (1989), “Great Britain's 'last battle' in the Middle East: notes on cabinet planning during the Suez crisis of 1956," The International History Review, vol. 11, no. 3, pp. 486-517. https://doi.org/10.1080/07075332.1989.9640522

European Commission (2017), White Paper on the Future of Europe: Reflections and scenarios for the EU27 by 2025, COM (2017) 2025, Brussels, 1.3.2017.

Germond, C. (2012), 'Dynamic Franco-German duos: Giscard-Schmidt and MitterrandKohl,' in E. Jones, A. Menon \& S. Weatherill (eds.) The Oxford Handbook of the European Union, Oxford: Oxford University Press, pp. 193-205.

https://doi.org/10.1093/oxfordhb/9780199546282.013.0014

Haastrup, T. (2013), 'EU as mentor? Promoting regionalism as external relations practice in EU-Africa relations,' Journal of European Integration, vol. 35, no. 7, pp. 785-800. https://doi.org/10.1080/07036337.2012.744754

Haywood, E. (1993). 'The European Policy of François Mitterrand,' JCMS: Journal of Common Market Studies, vol. 31, no. 2, pp. 269-282. https://doi.org/10.1111/j.1468-5965.1993.tb00462.x

Kerikmäe, T. \& Chochia, A., eds. (2016), Political and Legal Perspectives of the EU Eastern Partnership Policy, Cham, Heidelberg \& New York: Springer International Publishing. https://doi.org/10.1007/978-3-319-27383-9

Lange, P. (1993), 'Maastricht and the Social Protocol: why did they do it?' Politics \& Society, vol. 21, no. 1, pp. 5-36. https://doi.org/10.1177/0032329293021001002

Lauber, V. (1983), The Political Economy of France: from Pompidou to Mitterrand, Westport: Praeger Publishers.

Lewis, J. E. (1998), Gender, Social Care, and Welfare State Restructuring in Europe, Burlington: Ashgate.

Moravcsik, A. (1991). 'Negotiating the Single European Act: national interests and conventional statecraft in the European Community,' International Organization, vol. 45, no. 1, pp. 19-56.

https://doi.org/10.1017/S0020818300001387

Newton, J. M. (2003), Russia, France, and the Idea of Europe, Basingstoke: Palgrave Macmillan.

- (2013), 'Gorbachev, Mitterrand, and the emergence of the post-Cold War order in Europe,' Europe-Asia Studies, vol. 65, no. 2, pp. 290-320. https://doi.org/10.108 0/09668136.2012.759716

Pedersen, T. (1998), Germany, France and the Integration of Europe: A Realist Interpretation, London \& New York: Pinter.

Powell, C. (2015), The Long Road to Europe: Spain and the European Community, 1957-1986, Working Paper, 11 June 2015, Madrid: Elcano Royal Institute.

Ramiro Troitiño, D. (2008), 'De Gaulle and the European Communities,' Proceedings of the Institute for European Studies, no. 4, pp. 139-152. 
— (2013), European Integration: Building Europe, Hauppauge: Nova Science Publishers.

Ramiro Troitiño, D. \& Chochia, A. (2015), 'Winston Churchill and the European Union,' Baltic Journal of Law \& Politics, vol. 8, no. 1, pp. 55-81.

Rieker, P. (2006), 'From common defence to comprehensive security: Towards the Europeanization of French foreign and security policy?' Security Dialogue, vol. 37, no. 4, pp. 5095-5028. https://doi.org/10.1177/0967010606072507

Sakwa, R. (1990), Gorbachev and his Reforms, 1985-1990, New York: Prentice Hall.

Salmon, P. (2010), 'Preface,' in P. Salmon, K. Hamilton \& S. R. Twigge (eds.) Documents on British Policy Overseas, Series III, vol. VII, London: Routledge, pp. ix-xiv.

Schwab, K. (2016), 'The Global Competitiveness Report 2015-2016,' Geneva: World Economic Forum.

Short, P. (2013) Mitterrand: A Study in Ambiguity, London: The Bodley Head.

Single European Act (1987), Official Journal of the European Union, L 169, 29.07.1987, pp. $1-28$.

Sperling, J. (1993), 'A Unified Germany, a Single European Economic Space, and the Prospects for the Atlantic Economy,' in C. F. Lankowski (ed.) Germany and the European Community, New York: St. Martin's Press, pp. 179-216.

Tiersky, R. (1995), "Mitterrand's Legacies," Foreign Affairs, vol. 74, no. 1, pp. 112-121. https://doi.org/10.2307/20047023

Védrine, H. (2016), Les Mondes de François Mitterrand-Nouvelle édition: A l'Elysée 1981-1995, Paris: Fayard. 